\title{
Solvent Capacity of Different Substances on Gutta-Percha and Resilon
}

\author{
Mário TANOMARU-FILHO ${ }^{1}$ \\ Tais d' Azeredo ORLANDO ${ }^{1}$ \\ Eduardo Antunes BORTOLUZZI ${ }^{2}$ \\ Guilherme Ferreira da SILVA ${ }^{1}$ \\ Juliane Maria Guerreiro TANOMARU ${ }^{1}$ \\ ${ }^{1}$ Department of Restorative Dentistry, Araraquara Dental School, \\ São Paulo State University, Araraquara, SP, Brazil \\ ${ }^{2}$ Department of Dentistry, Florianópolis Dental School, Federal University of Santa Catarina, Florianópolis, SC, Brazil
}

\begin{abstract}
The aim of this study was to evaluate the effectiveness of 3 solvents (eucalyptol, orange oil, and xylol) on 2 types of gutta-percha (conventional and thermoplastic) and Resilon. Specimens ( $10 \mathrm{~mm}$ diameter $\mathrm{x} 1 \mathrm{~mm}$ thick; $\mathrm{n}=7$ per condition) were prepared and maintained at $37^{\circ} \mathrm{C}$ for $48 \mathrm{~h}$. Each specimen was weighed on a precision scale every $24 \mathrm{~h}$ until its mass was stable, at which time the initial mass was determined. Specimens $(n=7)$ were then immersed in the solvent solutions and, after $48 \mathrm{~h}$ at $37^{\circ} \mathrm{C}$, they were reweighed at $24-\mathrm{h}$ intervals, until stabilization (final mass). The difference between the final and the initial mass determined the solvent capacity of each solvent. Data were subjected to analysis of variance and Tukey's test at 5\% significance level. The results demonstrated that xylol was the most effective, especially on conventional gutta-percha and Resilon $(\mathrm{p}<0.05)$. Eucalyptol and orange oil were more effective on thermoplastic gutta-percha than the other materials $(\mathrm{p}<0.05)$. It was concluded that all evaluated substances presented solvent action, but xylol was the most effective on both gutta-percha or Resilon.
\end{abstract}

Key Words: Gutta-percha, retreatment, solvent, Resilon.

\section{INTRODUCTION}

The primary goal of the endodontic therapy is to completely fill and seal the root canal system. If these parameters are not achieved during endodontic therapy, failure might result $(1,2)$. When endodontic retreatment is indicated, removal of the filling material is an important step in determining its success $(3,4)$. Xylol and eucalyptol (5) are the most commonly used solvents.

An alternative solvent for gutta-percha and endodontic cements is orange oil (5-8). It is a readily available solvent, and may be a good alternative for use in endodontic retreatment, due to its lower toxicity compared to other substances $(5,6)$. Oyama et al. (6) evaluated the solvent action of xylol, eucalyptol, halotane, chloroform, and orange oil on gutta-percha in root canals filled with gutta-percha and N-Rickert cement.
Dissolution of gutta-percha was assessed by inserting a spacer $5 \mathrm{~mm}$ into the obturating cone. Results demonstrated that xylol and orange oil were more effective than the other solvents.

Resilon (Resilon Research LLC, Madison, CT, USA) is a thermoplastic synthetic polymer-based root canal filling material with similar properties to guttapercha (9). It is also presented as cones and is used in association with Ephiphany (Pentron Clinical Technologies, Wallingford, CT, USA), a dual-cured resin-based cement. Somma et al. (10), evaluating the removal of 3 different filling materials (gutta-percha, Resilon, and EndoRez) during retreatment, observed that all techniques left remnants of filling material on the root canal walls.

Magalhães (11) evaluated the solubility of guttapercha in 4 solvents: xylol, orange oil, eucalyptol, and chloroform. Xylol presented the best solvent capac- 
ity. Chloroform, orange oil, and eucalyptol performed similarly.

Martos et al. (7) evaluated the solubility of 3 types of root canal sealers in 3 organic solvents (eucalyptol, xylol, orange oil), and concluded that xylol and orange oil presented similar solvent effects with a significant solubility of the tested cements. The guidelines for choosing the ideal solvent for endodontic retreatment point to a balance between toxicity, clinical safety, and chemical solvent capacity. These characteristics should aid the clinician in solvent selection among the substances available (6).

Complete removal of existing root canal filling material is desirable during endodontic retreatment (12). Due to the introduction of alternatives to guttapercha, such as Resilon, the purpose if this study was to evaluate the solvent action of different substances on gutta-percha and Resilon.

\section{MATERIAL AND METHODS}

Two different types of gutta-percha - conventional gutta-percha (Endopoints, Paraíba do Sul, RJ, Brazil), and thermoplastic gutta-percha (Endopoints TP; Endopoints) - and Resilon (RE; Pentron Clinical Technologies) were used.

Seven specimens $(10 \mathrm{~mm}$ diameter x $1 \mathrm{~mm}$ thickness) from each material were fabricated for each evaluated solvent. The materials were immersed in water for $60 \mathrm{~s}$ in a water bath apparatus used to soften impression materials (Plastificador de Godiva Righetto e Cia., Campinas, SP, Brazil) at $70^{\circ} \mathrm{C}$, monitored by a digital thermometer.

Following that, the heated materials were placed in standard metallic ring molds with the previously described dimensions, and pressed between two glass slabs under constant controlled pressure of $0.5 \mathrm{~N}$ for $1 \mathrm{~min}$. Next, the specimens were maintained at $37^{\circ} \mathrm{C}$ for $24 \mathrm{~h}$.

The evaluated solvents were: xylol (Biodinâmica, Ibiporã, PR, Brazil), orange oil (Biodinâmica), and eucalyptol (Biodinâmica).
Each specimen, along with its metallic ring, was weighed at 24-h intervals until stabilization of the mass for determination of the initial mass in grams. After weighing on a precision scale (model BL 210S; Sartorius, Gottingen, Germany, accurate to 0.0001 ), the specimens were immersed in one of the solvents at $24 \pm 1^{\circ} \mathrm{C}$ for $5 \mathrm{~min}$, followed by immersion in distilled water for 20 $\min$ in order to neutralize the solvent action. After that, the specimens were removed from the water, stored at $37^{\circ} \mathrm{C}$ for $48 \mathrm{~h}$, and then reweighed at $24-\mathrm{h}$ intervals, until stabilization of the mass in order to determine the final mass. The difference between the initial and final mass was calculated to determine the solvent action.

Data were subjected to analysis of variance and Tukey's test at 5\% significance level.

\section{RESULTS}

Table 1 depicts the solvent action of eucalyptol, xilol and orange oil solvents on the studied root canal filling materials. The mean mass loss of gutta-percha and Resilon is presented.

\section{DISCUSSION}

Mechanical, thermal, or chemical techniques may be individually applied or combined for removal of filling materials during endodontic retreatment. However, it is often impossible to achieve complete removal of existing obturating materials from the canals $(13,14)$.

The present results demonstrated that xylol was

Table 1. Mean mass loss ( $\mathrm{g}$ ) and standard deviation of the filling materials after immersion in the different solvents.

\begin{tabular}{lccc}
\hline & $\begin{array}{c}\text { Conventional } \\
\text { gutta-percha }\end{array}$ & $\begin{array}{c}\text { Thermoplastic } \\
\text { gutta-percha }\end{array}$ & Resilon \\
\hline Xylol & $0.0017 \pm 0.0004 \mathrm{Ca}^{*}$ & $0.0035 \pm 0.0006 \mathrm{Ba}$ & $0.0198 \pm 0.002 \mathrm{Aa}$ \\
Eucalyptol & $0.0001 \pm 0.00001 \mathrm{Cb}$ & $0.0007 \pm 0.00001 \mathrm{Ac}$ & $0.0004 \pm 0.0002 \mathrm{Bb}$ \\
& & & $0.0013 \pm 0.0002 \mathrm{Ab}$ \\
\hline
\end{tabular}

Different uppercase letters indicate statistically significant difference among the endodontic filling materials $(\mathrm{p}<0.05)$. Different lowercase letters indicate statistically significant difference among the solvents $(\mathrm{p}<0.05)$. 
the solvent with the strongest action on Resilon. Orange oil presented no effect on Resilon, while eucalyptol had the lowest effect. A previous study (12) demonstrated that the Resilon/Epiphany system can be removed from the root canal with rotary files and chloroform.

In the present study, xylol was the most effective among the tested solvents in dissolving both conventional and thermoplastic gutta-percha. This finding is in agreement with those of Oyama et al. (6), but disagrees with the results of Martos et al. (7), who reported that orange oil and xylol presented similar solvent effect on gutta-percha.

Xylol is an aromatic organic solvent, usually available in the form of di-methyl-benzene. It presents as a universal solvent of organic substances, mainly hydrocarbons (which comprise the gutta-percha cones in the form of alkadienes) and the polyurethanes (which comprise the Resilon cones), probably due to destabilization of the covalent bonds between the carbon atoms (15).

De Oliveira et al. (12) compared filling material remnants and the working time necessary to remove gutta-percha/AH 26 and Resilon/Epiphany in root canals of extracted teeth. Retreatment was performed using chloroform and 2 rotary techniques (K3 and Liberator files). Resilon/Epiphany was effectively removed by both techniques. Hassanloo (13) studied the retreatment of root canals filled with Epiphany. Sixty roots had their canals obturated with the Epiphany/Resilon system (experimental) or gutta-percha/AH Plus (control). After 8 weeks, canals were retreated with or without chloroform. Filling material residues were found in all 3 levels of the root canals. It has been demonstrated that the substances with best solvent action on gutta-percha are also the most toxic (11). Xylol, which presented overall better results as a solvent for gutta-percha in the present study, is also known for its potentially irritant effect on periapical tissues.

In the present study, orange oil and eucalyptol had similar effects on conventional gutta-percha $(\mathrm{p}>0.05)$, but none was as effective as xylol. Magalhães (11), in 2007 evaluated the solubility of gutta-percha in 4 organic solvents used in Endodontics: xylol, orange oil, eucalyptol, chloroform, and observed stronger dissolution in xylol. Conversely, another study evaluating the efficacy of 5 solvents (xylol, eucalyptol, halotane, chloroform, and orange oil) on gutta-percha observed similar results for xylol and orange oil (6). Eucalyptol demonstrated greater solvent effect on thermoplastic gutta-percha, while conventional gutta-percha was the material least affected by eucalyptol.

The effect of solvents on endodontic sealers was evaluated by our research group in a previous study (16) demonstrating action of eucalyptol and xylol on zinc oxide and eugenol-based cement (Intrafill) and no effect of these solvents on resin-based cements (AH Plus, Epiphany, and Endo Rez) or silicone (Roeko Seal). Similar results were reported by Martos et al. (7). Erdemir et al. (17) tested the solvent action of chloroform and halotane and observed good results on Sultan U/P, Diaket, and Roeko Seal cements, but no action on the resin-based cements AH 26 and AH Plus.

Eucalyptol presented mild solvent action on conventional gutta-percha. Different authors $(11,18)$ recommend the use of essential oils in Endodontics due to their biocompatibility. These authors highlight eucalyptol and orange oil as effective alternatives for dissolving gutta-percha.

The present study demonstrated that all evaluated solvents (xylol, orange oil, and eucalyptol) presented stronger solvent effect on thermoplastic gutta-percha than on conventional gutta-percha. In fact, orange oil was only active on thermoplastic gutta-percha. This is probably related to the fact that thermoplastic cones contain a higher percentage of gutta-percha, in order to improve their thermoplastic properties (19). Gurgel-Filho et al. (19) evaluated chemically and radiographically 5 commercial brands of gutta-percha and observed different percentages of gutta-percha by weight. These varied from $14.5 \pm 0.70 \%$ for Dentsply gutta-percha cones to $20.4 \pm 0.40 \%$ for Analitic cones. Gurgel-Filho et al. (20) evaluated the ability of 5 different commercially available gutta-percha points to fill simulated lateral canals, showing that the brand of gutta-percha cone had an influence on the length of filling within lateral canals. This may be a reflection of the chemical formulation of the gutta-percha points. Regarding clinical implications of the findings of the present study, eucalyptol presented solvent effect on gutta-percha, while orange oil was particularly active on thermoplastic gutta-percha.

In conclusion, although all analyzed substances presented different solvent action, xylol was the most effective on both gutta-percha and Resilon.

\section{RESUMO}

O objetivo deste estudo foi avaliar a efetividade de 3 solventes 
em 2 tipos de guta-percha e no Resilon. Os materiais avaliados foram: guta convencional (Endo points), guta termoplastificada (Endo points TP) e cones de Resilon (RE). Amostras circulares medindo $10 \mathrm{~mm}$ de diâmetro e $1 \mathrm{~mm}$ de espessura foram preparadas, sendo mantidas a $37^{\circ} \mathrm{C}$ por $48 \mathrm{~h}$. Cada amostra, com o anel metálico, foi pesada em uma balança de precisão a cada $24 \mathrm{~h}$ até estabilização da massa, quando a massa inicial era determinada. As amostras $(\mathrm{n}=7)$ foram imersas, então, nas soluções solventes avaliadas (eucaliptol, óleo de laranja, e xilol). Após 48 h a $37^{\circ} \mathrm{C}$, as amostras foram pesadas outra vez a cada $24 \mathrm{~h}$, até a estabilização (massa final). A diferença entre a massa final e inicial determinou a capacidade solvente de cada material. Os dados foram submetidos à análise de variância em nível de significância de $5 \%$ e teste de Tukey. Os resultados demonstraram que o xylol foi mais eficaz solvente, especialmente na guta convencional e no Resilon $(\mathrm{p}<0,05)$. O eucaliptol e o óleo de laranja foram mais eficazes sobre a guta thermoplastificada em relação aos outros materiais obturadores $(\mathrm{p}<0,05)$. Conclui-se que todas as substâncias testadas apresentam ação solvente, contudo, o xilol foi o mais efetivo sobre a guta-percha ou Resilon.

\section{REFERENCES}

1. Tavares PB, Bonte E, Boukpessi T, Siqueira JF Jr, Lasfargues JJ. Prevalence of apical periodontitis in root canal-treated teeth from an urban French population: influence of the quality of root canal fillings and coronal restorations. J Endod 2009;35:810-813.

2. Maniglia-Ferreira C, Valverde GB, Silva JB Jr, de Paula RC, Feitosa JP, de Souza-Filho FJ. Clinical relevance of trans 1,4-polyisoprene aging degradation on the longevity of root canal treatment. Braz Dent J 2007;18:97-101.

3. Ezzie E, Fleury A, Solomon E, Spears R, He J. Efficacy of retreatment techniques for a resin-based root canal obturation material. J Endod 2006;32:341-344.

4. Dall'Agnol C, Hartmann MS, Barletta FB. Computed tomography assessment of the efficiency of different techniques for removal of root canal filling material. Braz Dent J 2008;19:306-312.

5. Scelza MF, Coil JM, Maciel AC, Oliveira LR, Scelza P. Comparative SEM evaluation of three solvents used in endodontic retreatment: an ex vivo study. J Appl Oral Sci 2008;16:24-29.

6. Oyama KO, Siqueira EL, Santos M. In vitro study of effect of solvent on root canal retreatment. Braz Dent J 2002;13:208-211.

7. Martos J, Gastal MT, Sommer L, Lund RG, Del Pino FA, Osinaga PW. Dissolving efficacy of organic solvents on root canal sealers. Clin Oral Invest 2006;10:50-54.
8. Scelza MFZ, Coil JM, Maciel ACC, Oliveira LR, Scelza P. Comparative SEM evaluation of three solvents used in endodontic retreatment: an ex vivo study. J Appl Oral Sci 2008;16:24-29.

9. Shipper G, Teixeira FB, Arnold RR, Trope M. An evaluation of microbial leakage in roots filled with a thermoplastic synthetic polymer-based root canal filling material (Resilon). J Endod 2004;30:341-347.

10. Somma F, Cammarota G, Plotino G, Grande NM, Pameijer CH. The effectiveness of manual and mechanical instrumentation for the retreatment of three different root canal filling materials. J Endod 2008;34:466-469.

11. Magalhães BS. Dissolving efficacy of some organic solvents on gutta-percha. Braz Oral Res 2007;21:303-307.

12. de Oliveira DP, Barbizam JV, Trope M, Teixeira FB. Comparison between gutta-percha and Resilon removal using two different techniques in endodontic retreatment. J Endod 2006;32:362-364.

13. Hassanloo A. Retreatment efficacy of the Epiphany soft resin obturation system. Int Endod J 2007;40:633-643.

14. Bueno CE, Delboni MG, de Araújo RA, Carrara HJ, Cunha RS. Effectiveness of rotary and hand files in gutta-percha and sealer removal using chloroform or chlorhexidine gel. Braz Dent J 2006; 17:139-143.

15. Wourms D, Campbell AD, Hicks ML, Pelleu GB. Alternative solvents to chloroform for gutta-percha removal. J Endod 1990;16:224-226.

16. Tanomaru Filho M, Jorge EG, Tanomaru JMG. Solvent capacity of eucalyptol and xylol on different endodontic sealers. Cienc Odontol Bras 2006;9:60-65.

17. Erdemir A, Adanir N, Belli S. In vitro evaluation of the dissolving effect of solvents on root canal sealers. J Oral Sci 2003;45:123126.

18. Uemura M, Hata G, Toda T, Weine FS. Effectiveness of eucalyptol and d-limolene as gutta-percha solvents. J Endod 1997;23:739741.

19. Gurgel-Filho ED, Andrade Feitosa JP, Teixeira FB, Monteiro de Paula RC, Araújo Silva JB, Souza Filho FJ. Chemical and X-ray analyses of five brands of dental gutta-percha cone. Int Endod J 2003;36:302-307.

20. Gurgel-Filho ED, Feitosa JP, Gomes BP, Ferraz CC, Souza-Filho FJ, Teixeira FB. Assessment of different gutta-percha brands during the filling of simulated lateral canals. Int Endod J 2006;39:113118.

Accepted October 21, 2009 